\title{
DOCUMENTÁRIO E CINEMA DA ASSERÇÃO PRESSUPOSTA SEGUNDO NOËL CARROLL
}

\begin{abstract}
André Bonotto
Doutorado.

Designação do Programa de Estudos: Programa de Pós-graduação em Multimeios.

Instituição: Universidade Estadual de Campinas - UNICAMP.

Resumo:

Esta tese de doutorado analisa o pensamento do filósofo analítico Noël Carroll a respeito do cinema documentário. Sua discussão sobre o documentário envolve os temas da objetividade, de intenções autorais, da indexação das obras e da dimensão do traço histórico das imagens. O ponto principal deste pensamento localiza-se em sua teoria do cinema da asserção pressuposta, o que constitui sua definição conceitual para este gênero fílmico. Apresentamos, de início, a formação filosófica e cinematográfica deste autor, ressaltando a posição que ele ocupa no campo dos estudos de cinema e as características do método da filosofia analítica que ele adota. Examinamos, a seguir, os textos onde Carroll apresenta seu pensamento sobre o documentário, discutindo detalhadamente os elementos presentes em sua teorização. Após isso, problematizamos alguns pontos de sua teoria, como o conceito de asserção, a relação entre a postura mental ficcional versus assertiva, e o papel do significado. Apontamos, por fim, relações entre o projeto teórico de Noël Carroll e outras abordagens no campo de estudos do cinema documentário.
\end{abstract}


Palavras-chave: Noël Carroll, documentário, cinema, Filosofia, gêneros cinematográficos.

Ano: 2014.

Orientador: Francisco Elinaldo Teixeira. 